\title{
Ventilator-associated pneumonia in neonates, infants and children
}

\author{
Mohammad Hassan Aelami ${ }^{1}$, Mojtaba Lotfi ${ }^{2}$ and Walter Zingg ${ }^{3 *}$
}

\begin{abstract}
Ventilator-associated pneumonia (VAP) is relatively common in mechanically-ventilated children, but there is a wide variation in reported VAP rates, depending on settings and geographical regions. Surveillance definitions in children are challenging. Although these are provided by the German nosocomial infection surveillance system and an independent Dutch group, the combination of clinical and radiologic signs leaves room for interpretation. Of note, the United States Centers for Disease Prevention and Control guidelines do not offer algorithms for neonates. Despite the fact that most experts agree on the low sensitivity and specificity of existing definitions, little has changed over the past years. However, the number of studies reporting on VAP prevention programs has increased in recent years. Single interventions, such as chlorhexidine mouth wash or stress ulcer prophylaxis, were not effective. Successful prevention programs combined multiple interventions, such as hand hygiene, glove and gown use for endotracheal tube manipulation, backrest elevation, oral care with chlorhexidine, stress ulcer prophylaxis, cuff pressure maintenance where appropriate, use of orogastric tubes, avoidance of gastric overdistension, and elimination of non-essential tracheal suction. These multimodal strategies have proved to be successful among neonates, infants, and children. Importantly, they are applicable in high- as well as in low- and middle-income countries. This review provides an update of VAP incidence rates and summarizes current knowledge on its epidemiology, risk factors, surveillance definitions, and prevention programs in the pediatric setting.
\end{abstract}

Keywords: Ventilator-associated pneumonia, Children, Neonates, Healthcare-associated infection

\section{Introduction}

Healthcare-associated infections (HAIs) are associated with morbidity, mortality, and prolonged hospitalization, and represent a serious threat to patient safety. Hospitalized children are a particularly vulnerable population [1]. The incidence of HAI in adult and pediatric intensive care units (PICUs) is high. This is due to the many invasive procedures and frequent antibiotic use, which put the patients at risk for infection and promote the emergence of multidrug-resistant organisms [2]. The use of invasive devices in PICUs, such as central vascular lines and mechanical ventilation, is similar to adult intensive care and thus the burden of ventilator-associated pneumonia (VAP) and other HAIs is also similar [3]. In this review, we describe the epidemiology of VAP, summarize

\footnotetext{
* Correspondence: walter.zingg@hcuge.ch

${ }^{3}$ Infection Control Program and WHO Collaborating Centre on Patient Safety, University of Geneva Hospitals, 4 Rue Gabrielle Perret-Gentil, 1211 Geneva 14, Switzerland

Full list of author information is available at the end of the article
}

risk factors, and discuss effective prevention measures in PICUs and neonatal ICUs (NICUs).

\section{Review \\ Literature search and selection strategy}

A Medline search was performed for publications prior to 1 May 2014 using the following search (MeSH) terms: "pneumonia, ventilator associated" AND (child* OR neonat* OR infant* OR pediatr* OR paediatr*) and also pneumonia AND (nosocomial OR "healthcare-associated" OR "healthcare associated" OR "health care associated") AND (ventilat* OR intubat" OR respirat*) AND (child* OR neonat* OR infant" OR pediatr* OR paediatr*). Cross-referencing from retrieved publications was used to complete the search, including manual searches of cited references and relevant abstracts. Publications were eligible to be analyzed if they addressed VAP in any inpatient pediatric population. A total of 443 titles and abstracts were screened; 95 were retained for discussion in this review. 
Table 1 Case definitions of hospital-acquired pneumonia in children stratified by different age groups

\begin{tabular}{ll}
\hline Neonates & Onset $>72 \mathrm{~h}$ after birth and one of the following \\
& radiologic criteria: \\
& -new or progressive infiltrates \\
& - consolidations \\
& -adhesions or fluid in lobar fissures/pleura
\end{tabular}

And

Worsening gas exchange $\left(\mathrm{SaO}_{2} \downarrow ; \mathrm{O}_{2}\right.$ requirement $\uparrow$; Ventilation parameters $\uparrow$ )

And

Four of the following signs and symptoms:

-fever $\left(>38.0^{\circ} \mathrm{C}\right)$, hypothermia $\left(<36.5^{\circ} \mathrm{C}\right)$, or temperature instability

-new onset or increasing bradycardia $(<80 / \mathrm{min})$ or tachycardia (>200/min)

-new onset or increasing tachypnoea ( $>60 / \mathrm{min})$ or apnoea (>20 seconds)

-new onset or increasing signs of dyspnoea (retractions, nasal flaring, grunting)

-increasing production of respiratory secretions and need for suctioning

-purulent tracheal secretion

-isolation of a pathogen in respiratory secretions

-elevated C-reactive protein ( $>20 \mathrm{mg} / \mathrm{L}$ )

I/T-ratio $>0.2$

Infants: 2-11 One of the following radiologic criteria: months
And

Worsening gas exchange $\left(\mathrm{SaO}_{2} \downarrow ; \mathrm{O}_{2}\right.$ requirement $\uparrow$; Ventilation parameters $\uparrow$ )

And

Three of the following signs and symptoms:

-fever $\left(>38.0^{\circ} \mathrm{C}\right)$, hypothermia $\left(<36.5^{\circ} \mathrm{C}\right)$, or temperature instability

-leucopenia $\left(<4000 \mathrm{WBC} / \mathrm{mm}^{3}\right)$ or leucocytosis $\left(\geq 15,000 \mathrm{WBC} / \mathrm{mm}^{3}\right)$ with left shift $(\geq 10 \%$ band forms)

-new onset of purulent sputum, or change in character of sputum, or increased respiratory secretions, or increased suctioning requirements

-apnoea or dyspnoea (tachypnoea, nasal flaring, retraction of chest wall, grunting)

-wheezing, rales, or rhonchi

-cough

-bradycardia (<100/min) or tachycardia (>170/min)
Table 1 Case definitions of hospital-acquired pneumonia in children stratified by different age groups (Continued)

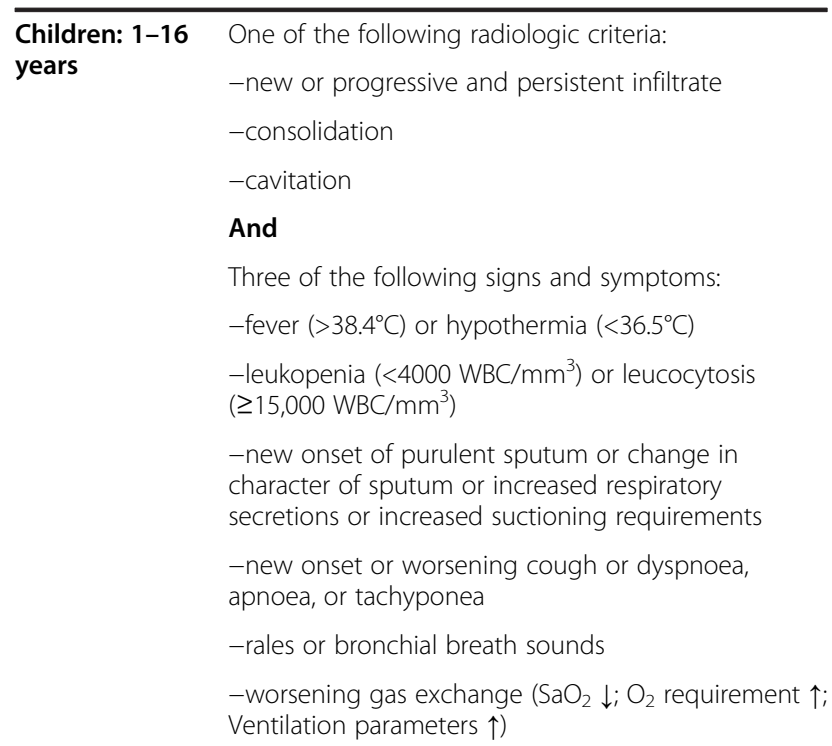

$\mathrm{SaO}_{2}$ : Oxygen saturation; I/T-ratio: immature to total neutrophil ratio; WBC: white blood cell count; $\uparrow$ : increase; $\downarrow$ : decrease.

\section{Definitions}

A uniform definition of VAP needs to have the capacity to be relevant for clinical trials, while balancing the risks of experimental therapy and sampling procedures with potential benefits for study patients [4]. If the definition of VAP is already controversial for adults, it is even more challenging for children, in particular for ventilated neonates. The starting point of the recent United States (US) Centers for Disease Prevention and Control (CDC) definitions for adults is a ventilator-associated complication (VAC), which is further narrowed towards infectious VAC and then towards possible or probable VAP, according to additional diagnostics [5]. However, It is not clear whether this algorithm can be applied to children in different age groups and, thus, the conventional CDC definitions of hospital-acquired pneumonia for children and neonates remain valid for the time being [6]. These definitions do not specify between "ventilated" or "non-ventilated" and the use of the term "VAP" depends on the time on ventilation ( $48 \mathrm{~h}$ or longer). The German national nosocomial infection surveillance system (Krankenhaus Infektions Surveillance System [KISS]) offers a definition for very low birth weight infants in their "Neo-KISS" module [7]. A Dutch study group established their own definition for VAP in neonates, which are more inclusive than the CDC definitions [8]. Table 1 summarizes the definitions of hospital-acquired pneumonia by stratifying age groups into neonates, infants ( $\leq 1$ year), and children ( $>1$ year to $\leq 16$ years). All definitions combine clinical and radiologic signs. In addition, the CDC and the European Centre for Disease Prevention and Control 
(ECDC) definitions further distinguish between definite, probable, and possible healthcare-associated pneumonia, based on microbiologic findings (Table 2) [9]. Clinical and radiologic findings lack sensitivity and specificity. However, tracheal aspirate cultures have also low sensitivity (31-69\%) and specificity (55-100\%). A positive tracheal culture alone does not discriminate between bacterial colonization and respiratory infection. Bronchoalveolar lavage (BAL) provides better results, but the range of sensitivity (11-90\%) and specificity (43-100\%) is large.

\section{Clinical criteria}

Clinical criteria for healthcare-associated pneumonia include fever, leukocytosis or leucopoenia, purulent secretions, new or worsening cough, dyspnoea, tachypnoea, crackles or bronchial breath sounds, and worsening gas exchange. These criteria are nonspecific and their sensitivity and specificity relative to the underlying pathology is poor [2]. Clinical findings must be combined with radiologic and microbiologic findings. In a study of 70 children with VAP, the modified clinical pulmonary infection score (mCPIS) of six or higher had a sensitivity of $94 \%$, a specificity of $50 \%$, a positive predictive value of $64 \%$, a negative predictive value of $90 \%$, and positive and likelihood ratios of 1.9 and 0.1 , respectively [10].

\section{Radiologic criteria}

Radiologic criteria include the presence of new or progressive pulmonary infiltrates, adhesions or fluid in lobar fissures/pleura, cavitations, air bronchograms, or pneumatoceles on chest $\mathrm{x}$-rays. The presence of air bronchograms has a higher sensitivity (58-83\%) than "evolving infiltrates" (50-78\%) [2]. Sequential chest x-rays (days -3 , $0,2,7)$ help to confirm healthcare-associated pneumonia in complex cases, such as children with underlying cardiac or pulmonary disease. Onset and progression of pneumonia in imaging is fast, but improvement takes time.

\section{Microbiologic criteria}

Respiratory cultures are obtained by tracheal aspirates, bronchoalveolar lavage (BAL), non-bronchoscopic BAL, or protected brush specimens (PBS) [10]. Thresholds are summarized in Table 2.

\section{Epidemiology}

Healthcare-associated pneumonia was the most common HAI in five studies [11-15], and second only to bacteremia in another two reports $[16,17]$. The range of VAP incidence density rates in both children and neonates is large. Rates as low as 1/1000 ventilator-days and as high as 63/1000 ventilator-days have been reported (Table 3). The incidence follows a geographical distribution and depends on the type of hospital and the country income level. A surveillance study from the International Nosocomial Infection Control Consortium (INICC) identified higher VAP rates in academic compared to nonacademic hospitals [18]. The same study reported higher rates in lower-middle-income compared to upper-middleincome countries. Extreme PICU rates have been reported from India (36.2\%) [19] and Egypt (31.8/1000 ventilatordays) [20]. Surveys in the USA and Germany found consistently lower rates (Table 3) [21-23]. However, high rates were reported also by high-income countries. A European multicenter study found that $23.6 \%$ of children admitted to a PICU developed VAP [24]. An Italian study identified $6.6 \%$ children with VAP among 451 on mechanical ventilation [25], and a mixed PICU in Australia identified $6.7 \%$ children with VAP among 269 on mechanical ventilation [26].

VAP is also common in the NICU and proportions between $6.8 \%$ and $57.0 \%$ of HAIs have been reported [34,60-66]. A Spanish study identified VAP in $9.1 \%$ of 198 neonates on mechanical ventilation [67]. In a Taiwanese NICU, $11.4 \%$ of 528 neonates had one or more HAIs, with VAP contributing to $18.6 \%$ [68]. An INICC

Table 2 Classification of hospital-acquired pneumonia in children based on microbiological results

\begin{tabular}{|c|c|}
\hline \multirow[t]{4}{*}{ Definite VAP } & A child who fulfils the case definitions for hospital-acquired pneumonia (Table 1) and has one of the following: \\
\hline & -same pathogen isolated from bronchial secretions/BAL and blood \\
\hline & $\begin{array}{l}\text { - pathogen or virus isolated from lung biopsy, or positive growth in culture of pleural fluid, or histopathologic examination with } \\
\text { evidence of pneumonia manifested as abscess formation, positive culture of lung parenchyma, or fungal hyphae }\end{array}$ \\
\hline & $\begin{array}{l}\text {-Pathogen or virus isolated from BAL (bacteria } \geq 10^{4} \mathrm{CFU} / \mathrm{ml} \text { ), or } \geq 5 \% \text { of BAL-obtained cells contain intracellular bacteria on direct } \\
\text { microscopic exam, or protected brush with a threshold of } \geq 10^{4} \mathrm{CFU} / \mathrm{ml} \text {, or distal protected aspirate with a threshold of } \geq 10^{4} \\
\text { CFU/ml, or positive exams for particular microorganisms (Legionella, Aspergillus, mycobacteria, Mycoplasma, Pneumocystis jirovecii) }\end{array}$ \\
\hline \multirow[t]{3}{*}{ Probable VAP } & A child who fulfils the case definitions for hospital-acquired pneumonia (Table 1) and has one of the following: \\
\hline & -pathogen isolated from BAL (bacteria $\left.<10^{4} \mathrm{CFU} / \mathrm{ml}\right)$ \\
\hline & $\begin{array}{l}\text { - pathogen or virus isolated from bronchial secretions, or quantitative culture of lower respiratory tract specimen (endotracheal } \\
\text { aspirate) with a threshold of bacteria } \geq 10^{6} \mathrm{CFU} / \mathrm{ml}\end{array}$ \\
\hline Possible VAP & $\begin{array}{l}\text { A child who fulfils the case definitions for hospital-acquired pneumonia (Table 1) with non-quantitative lower respiratory tract } \\
\text { specimen culture or no positive microbiology, but has been treated for hospital-acquired pneumonia }\end{array}$ \\
\hline
\end{tabular}


Table 3 Incidence densities and proportions of ventilator-associated pneumonia in pediatric settings

\begin{tabular}{|c|c|c|c|c|c|c|c|}
\hline Region & $\begin{array}{l}\text { Reference (Author, Country, Year of } \\
\text { publication, Ref No) }\end{array}$ & Setting & Patients & VAP* & VD* & $\begin{array}{l}\text { Incidence density (N/1000 } \\
\text { ventilation-days) }\end{array}$ & $\%$ \%* \\
\hline Middle & Afjeh, Iran, 2012 [27] & $\mathrm{NICU}^{*}$ & ${ }^{2} 81$ & 14 & 1207 & 11.6 & 17.3 \\
\hline \multirow[t]{2}{*}{ East/Persia } & Almuneef, Saudi Arabia, 2004 [28] & $\mathrm{PICU}^{*}$ & 2361 & 37 & 4173 & 8.9 & 10.3 \\
\hline & Shaath, Saudi Arabia, 2013 [29] & Cardiac surgery & ${ }^{1} 137$ & 9 & 306 & 29.4 & 6.6 \\
\hline South Asia & Awasthi, India, 2013 [19] & $\mathrm{PICU}^{*}$ & ${ }^{2} 105$ & 38 & - & - & 36.2 \\
\hline \multirow[t]{5}{*}{ East Asia } & Yuan, China, 2007 [30] & $\mathrm{NICU}^{*}$ & ${ }^{2} 259$ & 52 & 1130 & 46.0 & 20.1 \\
\hline & Navoa-Ng, Philippines, 2011 [31] & $\mathrm{PICU}^{*}$ & ${ }^{3} 252$ & 6 & 391 & 0.44 & 2.4 \\
\hline & Navoa-Ng, Philippines, 2011 [31] & $\mathrm{NICU}^{*}$ & ${ }^{3} 1813$ & 1 & 2279 & 12.8 & 0.06 \\
\hline & Xu, China, 2007 [32] & $\mathrm{NICU}^{*}$ & 33942 & 143 & 2259 & 63.3 & 3.6 \\
\hline & Cai, China, 2010 [33] & $\mathrm{NICU}^{*}$ & ${ }^{3} 1159$ & 38 & 779 & 48.8 & 3.3 \\
\hline \multirow[t]{11}{*}{ Europe } & Geffers, Germany, 2008 [21] & $\mathrm{NICU}^{*}(<1500 \mathrm{~g})$ & ${ }^{3} 8677$ & 176 & 64090 & 2.7 & 2.0 \\
\hline & Leistner, Germany, 2013 [22] & $\mathrm{NICU}^{*}(<1500 \mathrm{~g})$ & - & 345 & 158024 & 2.2 & - \\
\hline & Tekin, Turkey, 2013 [34] & $\mathrm{NICU} *$ & ${ }^{3} 6932$ & 76 & 11939 & 6.4 & 1.1 \\
\hline & Yalaz, Turkey, 2012 [35] & $\mathrm{NICU}^{*}$ & ${ }^{2} 162$ & 40 & 2907 & 13.8 & 24.7 \\
\hline & Patria, Italy, 2013 [25] & $\mathrm{PICU}^{*}$ & ${ }^{3} 451$ & 30 & - & - & 6.7 \\
\hline & Hentschel, Switzerland, 2005 [36] & $\mathrm{NICU}^{*}$ & ${ }^{1} 21$ & 1 & 80 & 12.5 & 4.8 \\
\hline & Roeleveld, Netherlands, 2011 [37] & Cardiac surgery & ${ }^{1} 125$ & 11 & 644 & 17.1 & 8.8 \\
\hline & Gastmeier, Germany, 2002 [38] & Burn unit & ${ }^{3} 41$ & 8 & 145 & 55.2 & 19.5 \\
\hline & Oezdemir, Turkey, 2011 [39] & $\mathrm{PICU}^{*}$ & ${ }^{3} 203$ & - & - & 15.7 & - \\
\hline & Jordan Garcia, Spain, 2014 [40] & $\mathrm{PICU}^{*}$ & ${ }^{3} 300$ & 4 & 422 & 9.5 & 1.3 \\
\hline & Turkish Neonatal Society; 2010 [41] & $\mathrm{NICU}^{*}$ & ${ }^{3} 9359$ & - & - & - & 1.7 \\
\hline North & Edwards, USA, 2008 [23] & $\mathrm{PICU}^{*}$ & - & 176 & 85809 & 2.1 & - \\
\hline \multirow[t]{10}{*}{ America } & Edwards, USA, 2008 [23] & $\mathrm{NICU}^{*}$ & - & 410 & 203466 & 2.0 & - \\
\hline & Edwards, USA, 2007 [42] & $\mathrm{PICU}^{*}$ & - & 81 & 32936 & 2.5 & - \\
\hline & Edwards, USA, 2007 [42] & $\mathrm{NICU}^{*}$ & - & 121 & 63075 & 1.9 & - \\
\hline & Hocevar, USA, 2012 [43] & $\mathrm{NICU}^{*}$ & - & 701 & 336527 & 2.1 & - \\
\hline & Stover, USA, 2001 [44] & $\mathrm{PICU}^{*}$ & - & - & - & 3.7 & - \\
\hline & Stover, USA, 2001 [44] & $\mathrm{NICU}^{*}$ & - & - & - & 2.5 & - \\
\hline & Apisarnthanarak, USA, 2003 [45] & $\mathrm{NICU}^{*}(\mathrm{ELBW})$ & ${ }^{2} 211$ & 24 & 4173 & 5.8 & 11.4 \\
\hline & Elward, USA, 2002 [46] & $\mathrm{PICU}^{*}$ & ${ }^{1} 595$ & 34 & 2931 & 11.6 & 5.1 \\
\hline & Weber, USA, 1997 [47] & Burn unit & ${ }^{1} 40$ & 7 & 614 & 11.4 & 17.5 \\
\hline & Martinez-Aguilar, Mexico, 2001 [48] & $\mathrm{PICU}^{*}$ & - & 44 & 1571 & 28 & - \\
\hline South & Abramczyk, Brazil, 2003 [11] & $\mathrm{PICU}^{*}$ & ${ }^{3} 515$ & 40 & 2120 & 18.7 & 7.8 \\
\hline \multirow[t]{7}{*}{ America } & Pessoa-Silva, Brazil, 2004 [49] & $\mathrm{NICU}^{*}$ & ${ }^{3} 4878$ & 83 & 10494 & 7.9 & 1.7 \\
\hline & Araujo da Silva Brazil, 2012 [50] & Homecare & ${ }^{1} 9$ & 23 & 3394 & 6.8 & - \\
\hline & Casado, Brazil, 2011 [51] & $\mathrm{PICU}^{*}$ & ${ }^{1} 366$ & 39 & 1439 & 27.1 & 10.7 \\
\hline & Duenas, Argentina, 2011 [52] & $\mathrm{PICU}^{*}$ & ${ }^{3} 1145$ & 93 & 7709 & 12.1 & 8.1 \\
\hline & Duenas, Argentina, 2011 [52] & $\mathrm{NICU} *$ & ${ }^{3} 1270$ & 139 & 8634 & 16.1 & 10.9 \\
\hline & Becerra, Peru, 2010 [53] & $\mathrm{PICU}^{*}$ & ${ }^{3} 414$ & 27 & 3420 & 7.9 & 6.5 \\
\hline & Fernandez Jonusas, Argentina, 2011 [54] & $\mathrm{NICU}^{*}$ & ${ }^{3} 1530$ & 6 & 3157 & 1.9 & 0.4 \\
\hline \multirow[t]{4}{*}{ Africa } & Rasslan, Egypt, 2012 [20] & $\mathrm{PICU}^{*}$ & ${ }^{3} 143$ & 18 & 567 & 31.8 & 12.6 \\
\hline & Rogers, South Africa, 2014 [55] & Burn unit & ${ }^{2} 92$ & 41 & - & 30.0 & 40.2 \\
\hline & El-Kholy, Egypt, 2012 [56] & $\mathrm{PICU}^{*}$ & ${ }^{1} 211$ & 54 & 1478 & 36.5 & 25.6 \\
\hline & El-Kholy, Egypt, 2012 [56] & $\mathrm{NICU}^{*}$ & ${ }^{1} 127$ & 26 & 1003 & 25.9 & 20.5 \\
\hline
\end{tabular}


Table 3 Incidence densities and proportions of ventilator-associated pneumonia in pediatric settings (Continued)

\begin{tabular}{llllllll}
\hline & Ben Jaballah, Tunisia, 2006 [57] & PICU/NICU* & ${ }^{3} 340$ & 7 & 1591 & 4.4 & 2.1 \\
& Badr, Egypt, 2011 [58] & NICU* $^{*}$ & ${ }^{2} 56$ & 32 & 315 & 101.6 & 57.1 \\
& El-Nawawy, Egypt, 2006 [59] & PICU* $_{*}^{*}$ & - & - & - & 10.9 & - \\
\hline
\end{tabular}

*NICU: neonatal intensive care unit; PICU: pediatric intensive care unit; VAP: ventilator-associated pneumonia; VD: ventilation days.

** Proportion of patients with ventilator-associated pneumonia compared to patients included in the study (admissions or patients on ventilation).

${ }^{1}$ Patients on mechanical ventilation for $24 \mathrm{~h}$ or more.

${ }^{2}$ Patients on mechanical ventilation for more than $48 \mathrm{~h}$.

${ }^{3}$ All admitted patients.

survey summarizing results from 30 NICUs in 15 countries reported significantly higher VAP rates in academic compared to non-academic institutions [69]. VAP incidence densities in an Iranian and Turkish NICU were $13.8 / 1000$ and 11.6/1000 ventilator-days, respectively $[27,35]$. A higher incidence was reported in another Iranian study with $42 \%$ of 38 neonates on mechanical ventilation [70]. Table 4 summarizes birth weight-dependent numbers from different studies [8,21-23,42-44,49,71].

Several studies from the USA, Italy, and Iran found that VAP prolonged mechanical ventilation by approximately $8-12$ days $[25,70,72,73]$, and this may even be as high as 56 days in extremely preterm neonates [46]. Prolonged length of stay was the main driver of attributable costs of up to US\$ 1040 in Iran and US\$ 51,157 in the USA $[70,73]$. There are no data on the attributable mortality of VAP. The mortality of HAI in the PICU is estimated to range between $5-14 \%[27,44]$, to which VAP may significantly contribute $(\mathrm{P}=0.04)$ [25].

\section{Risk factors}

Ventilation was the most important identified risk for HAI in a prevalence study of 21 hospitals in Mexico (odds ratio [OR], 2.3; 95\% confidence interval [CI], 1.2-4.1) [74]. Reintubation (OR, 2.7; CI, 1.2-6.2) and transport out of the PICU (OR, 8.9; CI, 3.8-20.7) were significant risk factors identified in a US PICU [74]. Other extrinsic risk factors include prior antibiotic therapy (OR, 2.89; CI, 1.41-5.94), bronchoscopy (OR, 4.48; CI, 2.31-8.71), immunosuppressive drugs (OR, 1.87; CI, 1.07-3.27), and the use of enteral feeding (OR, 8.78; CI, 2.13-36.20) [75-77]. A number of intrinsic factors predisposing for VAP have been reported, such as young age ( $<12$ months) $[75,78]$, subglottic or tracheal stenosis $(\mathrm{P}=0.02)$, trauma $(\mathrm{P}=0.02)$, tracheostomy $(\mathrm{P}=0.04)$ [72], gastroesophageal reflux [79], immunodeficiency [28], neuromuscular blockade $[28,75,80]$, genetic syndromes (OR, 2.04; CI, 1.08-3.86) [46,76], and gender (female: OR, 10.32; CI, 2.9-37.2) [77].

In neonates, the main risk factors are low birth weight (hazard ratio [HR], 1.37; CI, 1.0-1.9]) and mechanical ventilation (HR, 9.7; CI, 4.6-20.4) [8]. Time of mechanical ventilation was a main factor in Spanish (OR, 1.1; CI,1.1-1.2) [67], Chinese (OR, 4.8; CI, 2.2-10.4) [30], and Iranian studies $(\mathrm{P}<0.001)$ [70]. Reintubation, absence of tube feeding, and absence of stress ulcer prophylaxis were risk factors in Australia [26]. In an Italian study, reintubation $(\mathrm{P}<0.001)$, tracheostomy $(\mathrm{P}=0.04)$, and enteral feeding $(\mathrm{P}=0.02)$ were associated with VAP [25]. Risk factors for VAP are summarized in Table 5.

\section{Microorganisms}

The microorganism type and antibiotic susceptibility are variable according to the geographical region (Figure 1). Gram-negative pathogens predominate, but their contribution is exceptionally high in Asia. Overall, the most common pathogens are Pseudomonas aeruginosa, Acinetobacter baumannii, and Enterobacteriaceae. In Europe and North America Staphylococcus aureus predominate [8,77,81]. In Asia, most pathogens are multidrug-resistant [82-84]. A Greek group reported 65 children with 71 infections

Table 4 Incidence densities of ventilator-associated pneumonia in neonatal intensive care units stratified by birth weight

\begin{tabular}{|c|c|c|c|c|c|c|c|c|c|}
\hline $\begin{array}{l}\text { Weight } \\
\text { categories }\end{array}$ & $\begin{array}{l}\text { Edwards USA } \\
2007 \text { [42] }\end{array}$ & $\begin{array}{l}\text { Edwards USA } \\
2008[23]\end{array}$ & $\begin{array}{l}\text { Rosenthal INICC } \\
2010 \text { [71] }\end{array}$ & $\begin{array}{l}\text { Hocevar USA } \\
2012[43]\end{array}$ & $\begin{array}{l}\text { Stover USA } \\
2001[44]\end{array}$ & $\begin{array}{l}\text { Pessoa-Silva } \\
\text { Brazil } 2004 \text { [49] }\end{array}$ & $\begin{array}{l}\text { Van der Zwet } \\
\text { The Netherlands } \\
2005[8]\end{array}$ & $\begin{array}{l}\text { Geffers } \\
\text { Germany } \\
2008[21]\end{array}$ & $\begin{array}{l}\text { Leistner } \\
\text { Germany } \\
2013[22]\end{array}$ \\
\hline$\leq 750 \mathrm{~g}$ & 2.5 & 2.6 & 11.8 & 2.4 & $3.5^{*}$ & $7.0^{*}$ & $19.7^{*}$ & $2.8^{*}$ & $2.3^{*}$ \\
\hline $751-1000 \mathrm{~g}$ & 2.2 & 2.1 & 9.2 & 2.1 & & & & & \\
\hline $1001-1500 \mathrm{~g}$ & 1.4 & 1.5 & 8.2 & 1.3 & 4.9 & 9.2 & 14.7 & 2.3 & 1.6 \\
\hline $1501-2500 \mathrm{~g}$ & 1.1 & 1.0 & 7.2 & 0.9 & 1.1 & 7.8 & 5.8 & - & - \\
\hline$>2500 \mathrm{~g}$ & 1.2 & 0.9 & 6.2 & 0.7 & 0.9 & 8.3 & 7.4 & - & - \\
\hline
\end{tabular}

*Birth weight $\leq 1000 \mathrm{~g}$. 
Table 5 Risk factors for ventilator-associated pneumonia in pediatric and neonatal settings

\begin{tabular}{|c|c|c|c|c|c|c|c|}
\hline Risk factor & Reference (Author, Ref No) & Setting & Patients & VAP, $n$ & VAP, $\%$ & Odds ratio $[95 \% \mathrm{Cl}]$ & P-value \\
\hline Gender (female) & Srinivasan [77] & $\mathrm{NICU} / \mathrm{PICU}$ & 60 & 19 & 32 & $10.3[52.9-37.2]$ & $<0.001$ \\
\hline Genetic syndromes & Elward [46] & $\mathrm{PICU}$ & 595 & 34 & 5.1 & $2.4[1.0-5.5]$ & 0.043 \\
\hline Trauma & Bigham [72] & $\mathrm{PICU}$ & 2846 & 42 & 1.47 & - & 0.020 \\
\hline Post-surgical admission diagnosis & Srinivasan [77] & $\mathrm{NICU} / \mathrm{PICU}$ & 60 & 19 & 32 & $10.0[2.2-46.1]$ & 0.003 \\
\hline Subglottic or tracheal stenosis & Bigham [72] & $\mathrm{PICU}$ & 2846 & 42 & 1.47 & - & 0.020 \\
\hline PRISM III score > 10 & Roeleveld [37] & Cardiac surgery & 125 & 11 & 8.8 & 4.4 [1.1-18.0] & 0.041 \\
\hline \multirow[t]{2}{*}{ Prolonged ventilation } & Awasthi [19] & Ventilatory units & 105 & 38 & 36.2 & $3.8[1.4-10.0]$ & 0.008 \\
\hline & Casado [51] & $\mathrm{PICU}$ & 366 & 39 & 10.7 & $1.0[1.0-1.1]$ & 0.017 \\
\hline \multirow[t]{2}{*}{ Reintubation } & Patria [25] & $\mathrm{PICU}$ & 451 & 30 & 6.6 & $9.5[3.3-26.8]$ & $<0.001$ \\
\hline & Elward [46] & $\mathrm{PICU}$ & 595 & 34 & 5.1 & $2.7[1.2-6.2]$ & 0.011 \\
\hline \multirow[t]{2}{*}{ Tracheostomy } & Patria [25] & $\mathrm{PICU}$ & 451 & 30 & 6.6 & $4.4[1.0-20.0]$ & 0.040 \\
\hline & Bigham [72] & $\mathrm{PICU}$ & 2846 & 42 & 1.47 & - & 0.040 \\
\hline Bronchoscopy & Almuneef [28] & $\mathrm{PICU}$ & 361 & 37 & 10.3 & 5.0 [1.7-15.3] & $<0.001$ \\
\hline Use of gastric tube & Casado [51] & $\mathrm{PICU}$ & 366 & 39 & 10.7 & $2.9[1.4-5.9]$ & 0.003 \\
\hline \multirow[t]{3}{*}{ Enteral feeding } & Patria [25] & $\mathrm{PICU}$ & 451 & 30 & 6.6 & $13.2[1.5-114.2]$ & 0.020 \\
\hline & Srinivasan [77] & NICU/PICU & 60 & 19 & 32 & $8.8[2.1-36.2]$ & 0.003 \\
\hline & Almuneef [28] & $\mathrm{PICU}$ & 361 & 37 & 10.3 & $2.3[1.1-4.8]$ & 0.004 \\
\hline Prior antibiotic therapy & Almuneef [28] & $\mathrm{PICU}$ & 361 & 37 & 10.3 & $2.5[1.1-5.4]$ & 0.026 \\
\hline Administration of blood products & Srinivasan [77] & $\mathrm{NICU} / \mathrm{PICU}$ & 60 & 19 & 32 & $0.1[0.02-0.6]$ & 0.009 \\
\hline \multirow[t]{2}{*}{ Use of sedatives/analgesics } & Srinivasan [77] & NICU/PICU & 60 & 19 & 32 & $77.5[7.1-844.6]$ & $<0.001$ \\
\hline & Casado [51] & $\mathrm{PICU}$ & 366 & 39 & 10.7 & $2.5[1.3-4.7]$ & 0.007 \\
\hline Neuromuscular blockade & Da Silva [80] & $\mathrm{PICU}$ & 317 & - & 5 & - & 0.010 \\
\hline Transport out of the $\mathrm{PICU}^{*}$ & Elward [46] & $\mathrm{PICU}$ & 595 & 34 & 5.1 & $8.9[3.8-20.7]$ & $<0.001$ \\
\hline
\end{tabular}

VAP: ventilator-associated pneumonia; PICU: pediatric intensive care unit.

*Transport out of the PICU for diagnostic procedures or medical interventions.

(20 VAP) due to carbapenem-resistant Gram-negative pathogens [85]. Isolates included Pseudomonas spp. (41.1\%), Acinetobacter spp. (39.7\%), and Klebsiella spp. (19.2\%).

\section{Prevention}

Many interventions in different combinations have been shown to play a role in VAP prevention: hand hygiene, preferably with alcohol-based handrub; glove and gown use for endotracheal tube manipulation; backrest elevation of $30^{\circ}$ to $45^{\circ}$; oral care with chlorhexidine; stress ulcer prophylaxis; cuff pressure maintenance; use of orogastric tubes; avoidance of gastric overdistension; and elimination of nonessential tracheal suction [86]. Oral care with chlorhexidine compared to placebo in 96 children on mechanical ventilation was not effective in reducing VAP in a Brazilian study [87]. Similar results were reported in a placebo-controlled study with high VAP rates in North India [88] and a randomized trial among children undergoing cardiac surgery in Brazil [89]. Gastroesophageal reflux is a constant incident in mechanically- ventilated children, with alkaline reflux more common than acidic reflux [79]. Thus, stress ulcer prophylaxis is rather unlikely to prevent VAP and, consequently, neither sucralfate nor ranitidine were effective in VAP prevention in a small study [90]. Two studies showed that VAP rates are lower in neonates undergoing nasal continuous positive airway pressure compared to the use of mechanical ventilation $[21,36]$.

A prevention bundle reduced VAP from 7.8/1000 to $0.5 / 1000$ ventilator-days $(\mathrm{P}<0.001)$ in a US PICU with an estimated economy of 400 hospital-days and costsavings of US\$ 2,353,222 [73]. In another PICU, a bundle adapted to local needs by plan-do-study-act cycles reduced VAP rates in a similar manner [72]. The bundle addressed handling of ventilator circuits and oral suctioning, hand hygiene, regular oral care with chlorhexidine, and backrest elevation. By applying a multimodal intervention, three PICUs reduced the incidence of hospital-acquired pneumonia from 5.6 per 100 patients at baseline to 1.9 in the intervention $(\mathrm{P}=0.016)$ [91]. An educational program targeting resident physicians and nurses in a PICU of a lower-middle-income country resulted in a non-significant VAP reduction of $28 \%(\mathrm{P}=$ 0.21) [92]. A quality improvement intervention targeting 


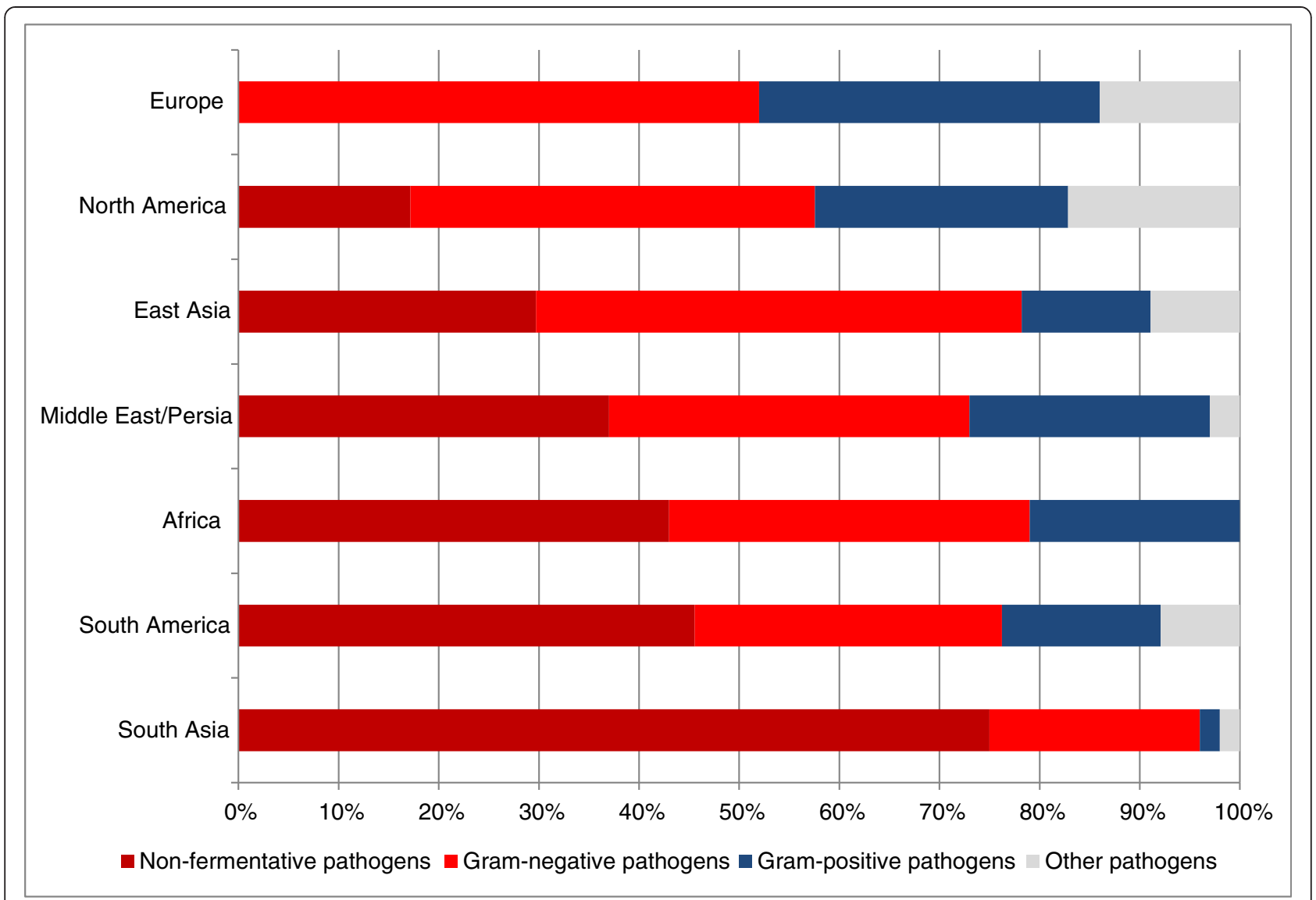

Figure 1 Geographical distribution of pathogens causing ventilator-associated pneumonia in children.

hand hygiene and establishing quality practices decreased VAP from $28.3 / 1000$ to $10.6 / 1000$ ventilator-days $(P=$ 0.005), which was sustainable over a long-term, follow-up period [93]. In a before-after study in eight PICUs of five developing countries, the efficacy of a multidimensional infection control program including education, outcome surveillance, process surveillance, and feedback on VAP rates and performance reduced VAP from 11.7/1000 to $8.1 / 1000$ ventilator-days $(P=0.02)$ [94]. The institution of a purpose-designed bundle by a nurse-led VAP surveillance program addressed backrest elevation; oral care using chlorhexidine; clean suctioning practice; ranitidine for all children not on full feeds; and four-hourly documentation [95]. After bundle implementation, no VAP was recorded over a 12-month period. The baseline ventilatorassociated tracheobronchitis rate of 3.9/1000 ventilatordays was reduced to $1.8 / 1000(\mathrm{P}=0.04)$ by implementing a multidisciplinary quality improvement initiative in another US PICU [96].

A strategy combining care practices with empowering the bedside nurse to lead bundle implementation in a NICU encouraged personal ownership and compliance with the bundle and finally reduced VAP by $31 \%$, resulting in savings of 72 hospital-days and US\$ 300,000 [97].
The INICC multidimensional infection control program was associated with significant reductions of VAP rates in the NICUs of 15 cities from 10 developing countries [98]. VAP rates at baseline and intervention were 17.8/ 1000 and 12.0/1000 ventilator-days, respectively [98]. Of 491 patients receiving mechanical ventilation in a Chinese NICU, the rate of VAP decreased from 48.8/1000 to $25.7 / 1000$ ventilator-days and further diminished to 18.5/1000 after hospital relocation and establishing a bundle of comprehensive preventive measures $(\mathrm{P}<0.001)$ [99].

\section{Conclusion}

VAP is common in mechanically-ventilated children with a wide variation of incidence density rates across geographical regions. Surveillance definitions are challenging in pediatric settings because the combination of clinical and radiologic signs leaves too much room for interpretation. This is particularly important in neonates, where CDC and INICC guidelines, and the German KISS program follows mainly the rationale of the definitions for older children. Gram-negative pathogens are the most common microorganisms, particularly $A$. baumannii and $P$. aeruginosa. However, there is a geographic variation with Gram-positive organisms more frequently observed 
in high-income compared to low- and middle-income countries. Similar to the evidence base of adult settings, a number of studies reported effective VAP prevention strategies. Successful programs combined multiple interventions, such as hand hygiene, glove and gown use for endotracheal tube manipulation, backrest elevation, oral care with chlorhexidine, stress ulcer prophylaxis, cuff pressure maintenance where appropriate, use of orogastric tubes, avoidance of gastric overdistension, and elimination of nonessential tracheal suction. When applied as a multimodal strategy by an interdisciplinary team, these interventions are most likely to be successful among neonates, infants, and children, and have proven effectiveness in high-, as well as in low- and middle-income countries.

\section{Competing interests}

The authors declare that they have no competing interests.

\section{Authors' contributions}

MHA, ML and WZ carried out the literature review. MHA provided the first draft of the manuscript. WZ participated in the coordination of the review and finalized the manuscript. All authors read and approved the final manuscript.

\section{Acknowledgments}

We would like to thank Rosemary Sudan for editorial support.

\section{Author details}

${ }^{1}$ Department of Pediatrics and Infection Control and Hand Hygiene Research Center, Imam Reza Hospital, School of Medicine, Mashhad University of Medical Sciences, Mashhad, Iran. ${ }^{2}$ Department of Pediatrics, School of Medicine, Mashhad University of Medical Sciences, Mashhad, Iran. ${ }^{3}$ Infection Control Program and WHO Collaborating Centre on Patient Safety, University of Geneva Hospitals, 4 Rue Gabrielle Perret-Gentil, 1211 Geneva 14, Switzerland.

Received: 2 June 2014 Accepted: 21 September 2014

Published: 30 September 2014

\section{References}

1. Klevens RM, Edwards JR, Richards CL Jr, Horan TC, Gaynes RP, Pollock DA, Cardo DM: Estimating health care-associated infections and deaths in U.S. hospitals, 2002. Public Health Rep 2007, 122:160-166.

2. Venkatachalam V, Hendley JO, Willson DF: The diagnostic dilemma of ventilator-associated pneumonia in critically ill children. Pediatr Crit Care Med 2011, 12:286-296.

3. Dudeck MA, Horan TC, Peterson KD, Allen-Bridson K, Morrell G, Anttila A, Pollock DA, Edwards JR: National Healthcare Safety Network report, data summary for 2011, device-associated module. Am J Infect Control 2013, 41:286-300.

4. Cotton MF, Berkowitz FE, Berkowitz Z, Becker PJ, Heney C: Nosocomial infections in black South African children. Pediatr Infect Dis J 1989, 8:676-683.

5. Magill SS, Klompas M, Balk R, Burns SM, Deutschman CS, Diekema D, Fridkin S, Greene L, Guh A, Gutterman D, Hammer B, Henderson D, Hess DR, Hill NS, Horan T, Kollef M, Levy M, Septimus E, Vanantwerpen C, Wright D, Lipsett P: Developing a new, national approach to surveillance for ventilator-associated events. Am J Crit Care 2013, 22:469-473.

6. Centers for Disease Prevention and Control; National Healthcare Safety Network: CDC/NHSN Surveillance Definitions for Specific Types of Infections. 2014, http://www.cdc.gov/nhsn/PDFs/pscManual/ 17pscNosInfDef_current.pdf.

7. Krankenhaus Infektions Surveillance System: Protokoll. Surveillance nosokomialer Infektionen bei Frühgeborenen mit einem Geburtsgewicht <1.500 g (NEO-KISS). 2009, http://www.nrz-hygiene.de/fileadmin/ nrz/download/NEOKISSProtokoll221209.pdf.

8. van der Zwet WC, Kaiser AM, van Elburg RM, Berkhof J, Fetter WP, Parlevliet GA, Vandenbroucke-Grauls CM: Nosocomial infections in a Dutch neonatal intensive care unit: surveillance study with definitions for infection specifically adapted for neonates. J Hosp Infect 2005, 61:300-311.

9. Langley JM, Bradley JS: Defining pneumonia in critically ill infants and children. Pediatr Crit Care Med 2005, 6(Suppl):S9-S13.

10. da Silva PS, de Aguiar VE, de Carvalho WB, Machado Fonseca MC: Value of clinical pulmonary infection score in critically ill children as a surrogate for diagnosis of ventilator-associated pneumonia. J Crit Care 2014, 29:545-550.

11. Abramczyk ML, Carvalho WB, Carvalho ES, Medeiros EA: Nosocomial infection in a pediatric intensive care unit in a developing country. Braz $J$ Infect Dis 2003, 7:375-380.

12. Diaz-Ramos RD, Solorzano-Santos F, Padilla-Barron G, Miranda-Novales MG, Gonzalez-Robledo R, Perez JA T y: [Nosocomial infections. Experience at a third-level pediatric hospital]. Salud Publica Mex 1999, 41(suppl 1):S12-S17.

13. Guardia Cami MT, Jordan Garcia I, Urrea Ayala M: [Nosocomial infections in pediatric patients following cardiac surgery]. An Pediatr (Barc) 2008, 69:34-38.

14. Lopes JM, Tonelli E, Lamounier JA, Couto BR, Siqueira AL, Komatsuzaki F, Champs AP, Starling CE: Prospective surveillance applying the national nosocomial infection surveillance methods in a Brazilian pediatric public hospital. Am J Infect Control 2002, 30:1-7.

15. Citak A, Karabocuoglu M, Ucsel R, Ugur-Baysal S, Uzel N: Bacterial nosocomial infections in mechanically ventilated children. Turk J Pediatr 2000, 42:39-42.

16. Grohskopf LA, Sinkowitz-Cochran RL, Garrett DO, Sohn AH, Levine GL, Siegel JD, Stover $\mathrm{BH}$, Jarvis WR: A national point-prevalence survey of pediatric intensive care unit-acquired infections in the United States. J Pediatr 2002, 140:432-438.

17. Grisaru-Soen G, Paret G, Yahav D, Boyko V, Lerner-Geva L: Nosocomial infections in pediatric cardiovascular surgery patients: a 4-year survey. Pediatr Crit Care Med 2009, 10:202-206.

18. Rosenthal VD, Jarvis WR, Jamulitrat $S$, Silva CP, Ramachandran $B$, Duenas $L$, Gurskis V, Ersoz G, Novales MG, Khader IA, Ammar K, Guzman NB, Navoa-Ng JA Seliem ZS, Espinoza TA, Meng CY, Jayatilleke K, International Nosocomial Infection Control Consortium: Socioeconomic impact on device-associated infections in pediatric intensive care units of 16 limited-resource countries: international Nosocomial Infection Control Consortium findings. Pediatr Crit Care Med 2012, 13:399-406.

19. Awasthi S, Tahazzul M, Ambast A, Govil YC, Jain A: Longer duration of mechanical ventilation was found to be associated with ventilator-associated pneumonia in children aged 1 month to 12 years in India. J Clin Epidemiol 2013, 66:62-66.

20. Rasslan O, Seliem ZS, Ghazi IA, El Sabour MA, El Kholy AA, Sadeq FM, Kalil M, Abdel-Aziz D, Sharaf HY, Saeed A, Agha H, El-Abdeen SA, El Gafarey M, El Tantawy A, Fouad L, Abel-Haleim MM, Muhamed T, Saeed H, Rosenthal VD: Device-associated infection rates in adult and pediatric intensive care units of hospitals in Egypt. International Nosocomial Infection Control Consortium (INICC) findings. J Infect Public Health 2012, 5:394-402.

21. Geffers C, Baerwolff S, Schwab F, Gastmeier P: Incidence of healthcareassociated infections in high-risk neonates: results from the German surveillance system for very-low-birthweight infants. J Hosp Infect 2008, 68:214-221.

22. Leistner R, Piening B, Gastmeier P, Geffers C, Schwab F: Nosocomial infections in very low birthweight infants in Germany: current data from the National Surveillance System NEO-KISS. Klin Padiatr 2013, 225:75-80.

23. Edwards JR, Peterson KD, Andrus ML, Dudeck MA, Pollock DA, Horan TC: National Healthcare Safety Network (NHSN) Report, data summary for 2006 through 2007, issued November 2008. Am J Infect Control 2008, 36:609-626.

24. Raymond J, Aujard Y: Nosocomial infections in pediatric patients: a European, multicenter prospective study. European Study Group Infect Control Hosp Epidemiol 2000, 21:260-263.

25. Patria MF, Chidini G, Ughi L, Montani C, Prandi E, Galeone C, Calderini E, Esposito S: Ventilator-associated pneumonia in an Italian pediatric intensive care unit: a prospective study. World J Pediatr 2013, 9:365-368.

26. Gautam A, Ganu SS, Tegg OJ, Andresen DN, Wilkins BH, Schell DN: Ventilator-associated pneumonia in a tertiary paediatric intensive care unit: a 1-year prospective observational study. Crit Care Resusc 2012, $14: 283-289$.

27. Afjeh SA, Sabzehei MK, Karimi A, Shiva F, Shamshiri AR: Surveillance of ventilator-associated pneumonia in a neonatal intensive care unit: characteristics, risk factors, and outcome. Arch Iran Med 2012, 15:567-571. 
28. Almuneef $\mathrm{M}$, Memish ZA, Balkhy HH, Alalem $\mathrm{H}$, Abutaleb $\mathrm{A}$ : Ventilatorassociated pneumonia in a pediatric intensive care unit in Saudi Arabia: a 30-month prospective surveillance. Infect Control Hospital Epidemiol 2004, 25:753-758.

29. Shaath GA, Jijeh A, Faruqui F, Bullard L, Mehmood A, Kabbani MS: Ventilator-associated pneumonia in children after cardiac surgery. Pediatr Cardiol 2014, 35:627-631.

30. Yuan TM, Chen LH, Yu HM: Risk factors and outcomes for ventilator-associated pneumonia in neonatal intensive care unit patients. J Perinat Med 2007, 35:334-338.

31. Navoa-Ng JA, Berba R, Galapia YA, Rosenthal VD, Villanueva VD, Tolentino MC, Genuino GA, Consunji RJ, Mantaring JB 3rd: Device-associated infections rates in adult, pediatric, and neonatal intensive care units of hospitals in the Philippines: International Nosocomial Infection Control Consortium (INICC) findings. Am J Infect Control 2011, 39:548-554.

32. Xu Y, Zhang $L$, Ge HY, Wang DH: [Clinical analysis of nosocomial infection in neonatal intensive care units]. Zhonghua Er Ke Za Zhi 2007, 45:437-441

33. Cai XD, Cao Y, Chen C, Yang Y, Wang CQ, Zhang L, Ding H: [Investigation of nosocomial infection in the neonatal intensive care unit]. Zhongguo Dang Dai Er Ke Za Zhi 2010, 12:81-84.

34. Tekin R, Dal T, Pirinccioglu H, Oygucu SE: A 4-year surveillance of deviceassociated nosocomial infections in a neonatal intensive care unit. Pediatr Neonatol 2013, 54:303-308.

35. Yalaz M, Altun-Koroglu O, Ulusoy B, Yildiz B, Akisu M, Vardar F, Ozinel MA, Kultursay N: Evaluation of device-associated infections in a neonatal intensive care unit. Turk J Pediatr 2012, 54:128-135.

36. Hentschel J, Brungger B, Studi K, Muhlemann K: Prospective surveillance of nosocomial infections in a Swiss NICU: low risk of pneumonia on nasal continuous positive airway pressure? Infection 2005, 33:350-355.

37. Roeleveld PP, Guijt D, Kuijper EJ, Hazekamp MG, de Wilde RB, de Jonge E: Ventilator-associated pneumonia in children after cardiac surgery in The Netherlands. Intensive Care Med 2011, 37:1656-1663.

38. Gastmeier P, Weigt O, Sohr D, Ruden H: Comparison of hospital-acquired infection rates in paediatric burn patients. J Hosp Infect 2002, 52:161-165.

39. Ozdemir H, Kendirli T, Ergun H, Ciftci E, Tapisiz A, Guriz H, Aysev D, Ince E, Dogru U: Nosocomial infections due to Acinetobacter baumannii in a pediatric intensive care unit in Turkey. Turk J Pediatr 2011, 53:255-260

40. Jordan Garcia I, Arriourtua AB, Torre JA, Anton JG, Vicente JC, Gonzalez CT: [A national multicentre study on nosocomial infections in PICU]. An Pediatr (Barc) 2014, 80:28-33.

41. Turkish Neonatal Society; Nosocomial Infections Study Group: Nosocomial infections in neonatal units in Turkey: epidemiology, problems, unit policies and opinions of healthcare workers. Turk J Pediatr 2010, 52:50-57.

42. Edwards JR, Peterson KD, Andrus ML, Tolson JS, Goulding JS, Dudeck MA, Mincey RB, Pollock DA, Horan TC: National Healthcare Safety Network (NHSN) Report, data summary for 2006, issued June 2007. Am J Infect Control 2007, 35:290-301.

43. Hocevar SN, Edwards JR, Horan TC, Morrell GC, Iwamoto M, Lessa FC Device-associated infections among neonatal intensive care unit patients: incidence and associated pathogens reported to the National Healthcare Safety Network, 2006-2008. Infect Control Hosp Epidemiol 2012, 33:1200-1206.

44. Stover BH, Shulman ST, Bratcher DF, Brady MT, Levine GL, Jarvis WR: Nosocomial infection rates in US children's hospitals' neonatal and pediatric intensive care units. Am J Infect Control 2001, 29:152-157.

45. Apisarnthanarak A, Holzmann-Pazgal G, Hamvas A, Olsen MA, Fraser VJ: Ventilator-associated pneumonia in extremely preterm neonates in a neonatal intensive care unit: characteristics, risk factors, and outcomes. Pediatrics 2003, 112:1283-1289.

46. Elward AM, Warren DK, Fraser VJ: Ventilator-associated pneumonia in pediatric intensive care unit patients: risk factors and outcomes. Pediatrics 2002, 109:758-764.

47. Weber JM, Sheridan RL, Pasternack MS, Tompkins RG: Nosocomial infections in pediatric patients with burns. Am J Infect Control 1997, 25:195-201.

48. Martinez-Aguilar G, Anaya-Arriaga MC, Avila-Figueroa C: [Incidence of nosocomial bacteremia and pneumonia in pediatric unit]. Salud Publica Mex 2001, 43:515-523.

49. Pessoa-Silva CL, Richtmann R, Calil R, Santos RM, Costa ML, Frota AC, Wey SB: Healthcare-associated infections among neonates in Brazil. Infect Control Hosp Epidemiol 2004, 25:772-777.
50. Araujo Da Silva AR, Vieira De Souza C, Viana Guimaraes ME, Sargentelli G, Ribeiro Gomes MZ: Incidence rates of healthcare-associated infection in a pediatric home healthcare service. Infect Control Hosp Epidemiol 2012, 33:845-848.

51. Casado RJ, de Mello MJ, de Aragao RC, de Albuquerque MF, Correia JB: Incidence and risk factors for health care-associated pneumonia in a pediatric intensive care unit. Crit Care Med 2011, 39:1968-1973.

52. Duenas $L$, Bran De Casares $A$, Rosenthal VD, Jesus Machuca L: Device-associated infections rates in pediatrics and neonatal intensive care units in El Salvador: findings of the INICC. J Infect Develop Ctries 2011, 5:445-451.

53. Becerra MR, Tantalean JA, Suarez VJ, Alvarado MC, Candela JL, Urcia FC: Epidemiologic surveillance of nosocomial infections in a pediatric intensive care unit of a developing country. BMC Pediatr 2010, 10:66.

54. Fernandez Jonusas S, Brener Dik P, Mariani G, Fustinana C, Marco Del Pont J: [Nosocomial infections in a neonatal unit: surveillance program]. Arch Argent Pediatr 2011, 109:398-405.

55. Rogers E, Alderdice F, McCall E, Jenkins J, Craig S: Reducing nosocomial infections in neonatal intensive care. J Matern Fetal Neonatal Med 2010 23:1039-1046

56. El-Kholy A, Saied T, Gaber M, Younan MA, Haleim MM, El-Sayed H, El-Karaksy $H$, Bazara'a H, Talaat M: Device-associated nosocomial infection rates in intensive care units at Cairo University hospitals: first step toward initiating surveillance programs in a resource-limited country. Am J Infect Control 2012, 40:e216-e220

57. Ben Jaballah N, Bouziri A, Kchaou W, Hamdi A, Mnif K, Belhadj S, Khaldi A, Kazdaghli K: [Epidemiology of nosocomial bacterial infections in a neonatal and pediatric Tunisian intensive care unit]. Med Mal Infect 2006, 36:379-385.

58. Badr MA, Ali YF, Albanna EA, Beshir MR, Amr GE: Ventilator associated pneumonia in critically-ill neonates admitted to neonatal intensive care unit, zagazig university hospitals. Iran J Pediatr 2011, 21:418-424.

59. El-Nawawy AA, Abd El-Fattah MM, Metwally HA, Barakat SS, Hassan IA: One year study of bacterial and fungal nosocomial infections among patients in pediatric intensive care unit (PICU) in Alexandria. J Trop Pediatr 2006, 52:185-191.

60. Garland JS, Uhing MR: Strategies to prevent bacterial and fungal infection in the neonatal intensive care unit. Clin Perinatol 2009, 36:1-13.

61. Elster T, Beata Czeszynska M, Sochaczewska D, Konefal H, Baryla-Pankiewicz E: [Analysis of risk factors for nosocomial infections in the neonatal intensive care unit of the Pomeranian Medical University in Szczecin in the years 2005-2008]. Ginekol Pol 2009, 80:609-614.

62. Couto RC, Pedrosa TM, Tofani Cde P, Pedroso ER: Risk factors for nosocomial infection in a neonatal intensive care unit. Infect Control Hosp Epidemiol 2006, 27:571-575.

63. Helwich E, Wojkowska-Mach J, Borszewska-Kornacka M, Gadzinowski J, Gulczynska E, Kordek A, Pawlik D, Szczapa J, Domanska J, Klamka J, Heczko PB: Epidemiology of infections in very low birth weight infants. Polish Neonatology Network research. Med Wieku Rozwoj 2013, 17:224-231.

64. Mahfouz AA, Al-Azraqi TA, Abbag Fl, Al-Gamal MN, Seef S, Bello CS: Nosocomial infections in a neonatal intensive care unit in south-western Saudi Arabia. East Mediterr Health J 2010, 16:40-44.

65. Broughton El, Lopez SR, Aguilar MN, Somarriba MM, Perez M, Sanchez N: Economic analysis of a pediatric ventilator-associated pneumonia prevention initiative in Nicaragua. Int J Pediatr 2012, 2012:359-430.

66. Yapicioglu H, Ozcan K, Sertdemir Y, Mutlu B, Satar M, Narli N, Tasova Y: Healthcare-associated infections in a neonatal intensive care unit in Turkey in 2008: incidence and risk factors, a prospective study. J Trop Pediatr 2011, 57:157-164

67. Cernada M, Aguar M, Brugada M, Gutierrez A, Lopez UL, Castell M, Vento M: Ventilator-associated pneumonia in newborn infants diagnosed with an invasive bronchoalveolar lavage technique: a prospective observational study. Pediatr Crit Care Med 2013, 14:55-61.

68. Su BH, Hsieh HY, Chiu HY, Lin HC: Nosocomial infection in a neonatal intensive care unit: a prospective study in Taiwan. Am J Infect Control 2007, 35:190-195.

69. Rosenthal VD, Lynch P, Jarvis WR, Khader IA, Richtmann R, Jaballah NB, Aygun C, Villamil-Gomez W, Duenas L, Atencio-Espinoza T, Navoa-Ng JA, Pawar M, Sobreya-Oropeza M, Barkat A, Mejia N, Yuet-meng C, Apisarnthanarak A, International Nosocomial Infection Control Consortium members: Socioeconomic impact on device-associated infections in limited-resource neonatal intensive care units: findings of the INICC. Infection 2011, 39:439-450. 
70. Moradi M, Nili F, Nayeri F, Amini E, T. E: Study of characteristics, risk factors and outcome for ventilator associated pneumonia in neonatal intensive care unit patients. Tehran Univ Med J 2013, 71:373-381.

71. Rosenthal VD, Maki DG, Jamulitrat S, Medeiros EA, Todi SK, Gomez DY, Leblebicioglu H, Abu Khader I, Miranda Novales MG, Berba R, Ramirez Wong FM, Barkat A, Pino OP, Duenas L, Mitery Z, Bijie H, Gurskis V, Kanj SS, Mapp T, Hidalgo RF, Ben Jaballah N, Raka LGikas A, Ahmed A, le TA T, Guzman Siritt ME, INICC Members: International Nosocomial Infection Control Consortium (INICC) report, data summary for 2003-2008, issued June 2009. Am J Infect 2010, 38:95-104. e2.

72. Bigham MT, Amato R, Bondurrant P, Fridriksson J, Krawczeski CD, Raake J, Ryckman S, Schwartz S, Shaw J, Wells D, Brilli RJ: Ventilator-associated pneumonia in the pediatric intensive care unit: characterizing the problem and implementing a sustainable solution. J Pediatr 2009, 154:582-587 e582.

73. Brilli RJ, Sparling KW, Lake MR, Butcher J, Myers SS, Clark MD, Helpling A, Stutler ME: The business case for preventing ventilator-associated pneumonia in pediatric intensive care unit patients. Jt Comm J Qual Pat Safety 2008, 34:629-638.

74. Avila-Figueroa C, Cashat-Cruz M, Aranda-Patron E, Leon AR, Justiniani N, Perez-Ricardez L, Avila-Cortes F, Castelan M, Becerril R, Herrera EL: [Prevalence of nosocomial infections in children: survey of 21 hospitals in Mexico]. Salud Publ Mex 1999, 41(suppl 1):S18-S25.

75. Fayon MJ, Tucci M, Lacroix J, Farrell CA, Gauthier M, Lafleur L, Nadeau D: Nosocomial pneumonia and tracheitis in a pediatric intensive care unit: a prospective study. Am J Respir Crit Care Med 1997, 155:162-169.

76. Liu B, Li SQ, Zhang SM, XU P, Zhang X, Zhang YH, Chen WS, Zhang WH: Risk factors of ventilator-associated pneumonia in pediatric intensive care unit: a systematic review and meta-analysis. J Thorac Dis 2013, 5:525-531

77. Srinivasan R, Asselin J, Gildengorin G, Wiener-Kronish J, Flori HR: A prospective study of ventilator-associated pneumonia in children. Pediatrics 2009, 123:1108-1115.

78. Samransamruajkit R, Jirapaiboonsuk S, Siritantiwat S, Tungsrijitdee O, Deerojanawong J, Sritippayawan S, Prapphal N: Effect of frequency of ventilator circuit changes ( 3 vs 7 days) on the rate of ventilator-associated pneumonia in PICU. J Crit Care 2010, 25:56-61

79. Abdel-Gawad TA, El-Hodhod MA, Ibrahim HM, Michael YW: Gastroesophageal reflux in mechanically ventilated pediatric patients and its relation to ventilator-associated pneumonia. Crit Care 2009, 13:R164.

80. Da Silva PS, Neto HM, de Aguiar VE, Lopes E Jr, de Carvalho WB: Impact of sustained neuromuscular blockade on outcome of mechanically ventilated children. Pediatr Int 2010, 52:438-443.

81. Patel JC, Mollitt DL, Pieper P, Tepas JJ 3rd: Nosocomial pneumonia in the pediatric trauma patient: a single center's experience. Crit Care Med 2000, 28:3530-3533

82. Xu XF, Ma XL, Chen Z, Shi LP, Du LZ: Clinical characteristics of nosocomial infections in neonatal intensive care unit in eastern China. J Perinat Med 2010, 38:431-437.

83. Zhang DS, Chen C, Zhou W, Yao YJ, Chen J: [The risk factors of ventilator-associated pneumonia in newborn and the changes of isolated pathogens]. Sichuan Da Xue Xue Bao Yi Xue Ban 2013, 44:584-587.

84. Zhang DS, Chen C, Zhou W, Chen J, Mu DZ: [Pathogens and risk factors for ventilator-associated pneumonia in neonates]. Zhongguo Dang Dai Er Ke Za Zhi 2013, 15:14-18.

85. Maltezou HC, Kontopidou F, Katerelos P, Daikos G, Roilides E, Theodoridou M: Infections caused by carbapenem-resistant Gram-negative pathogens in hospitalized children. Pediatr Infect Dis J 2013, 32:e151-e154.

86. Pittet D, Zingg W: Reducing ventilator-associated pneumonia: when process control allows outcome improvement and even benchmarking Crit Care Med 2010, 38:983-984

87. Kusahara DM, Peterlini MA, Pedreira ML: Oral care with $0.12 \%$ chlorhexidine for the prevention of ventilator-associated pneumonia in critically ill children: randomised, controlled and double blind trial. Int $J$ Nurs Stud 2012, 49:1354-1363.

88. Sebastian MR, Lodha R, Kapil A, Kabra SK: Oral mucosal decontamination with chlorhexidine for the prevention of ventilator-associated pneumonia in children - a randomized, controlled trial. Pediatr Crit Care Med 2012, 13:e305-e310.

89. Jacomo AD, Carmona F, Matsuno AK, Manso PH, Carlotti AP: Effect of oral hygiene with $0.12 \%$ chlorhexidine gluconate on the incidence of nosocomial pneumonia in children undergoing cardiac surgery. Infect Control Hosp Epidemiol 2011, 32:591-596.

90. Lopriore E, Markhorst DG, Gemke RJ: Ventilator-associated pneumonia and upper airway colonisation with Gram-negative bacilli: the role of stress ulcer prophylaxis in children. Intensive Care Med 2002, 28:763-767.

91. Gurskis V, Asembergiene J, Kevalas R, Miciuleviciene J, Pavilonis A Valinteliene R, Dagys A: Reduction of nosocomial infections and mortality attributable to nosocomial infections in pediatric intensive care units in Lithuania. Medicina (Kaunas) 2009, 45:203-213.

92. Gupta A, Kapil A, Kabra SK, Lodha R, Sood S, Dhawan B, Das BK, Sreenivas V: Assessing the impact of an educational intervention on ventilator-associated pneumonia in a pediatric critical care unit. Am J Infect Control 2014, 42:111-115.

93. Esteban E, Ferrer R, Urrea M, Suarez D, Rozas L, Balaguer M, Palomeque A, Jordan I: The impact of a quality improvement intervention to reduce nosocomial infections in a PICU. Pediatr Crit Care Med 2013, 14:525-532.

94. Rosenthal VD, Alvarez-Moreno C, Villamil-Gomez W, Singh S, Ramachandran B, Navoa-Ng JA, Duenas L, Yalcin AN, Ersoz G, Menco A, Arrieta P, Bran-de Casares AC, de Jesus Machuca L, Radhakrishnan K, Villanueva VD, Tolentino MC, Turhan O, Keskin S, Gumus E, Dursun O, Kaya A, Kuyucu N: Effectiveness of a multidimensional approach to reduce ventilator-associated pneumonia in pediatric intensive care units of 5 developing countries: International Nosocomial Infection Control Consortium findings. Am J Infect Control 2012, 40:497-501.

95. Brierley J, Highe L, Hines S, Dixon G: Reducing VAP by instituting a care bundle using improvement methodology in a UK paediatric intensive care unit. Europ J Pediatr 2012, 171:323-330.

96. Muszynski JA, Sartori J, Steele L, Frost R, Wang W, Khan N, Lee A, Lin A, Hall $M W$, Ayad O: Multidisciplinary quality improvement initiative to reduce ventilator-associated tracheobronchitis in the PICU. Pediatr Crit Care Med 2013, 14:533-538.

97. Ceballos K, Waterman K, Hulett T, Makic MB: Nurse-driven quality improvement interventions to reduce hospital-acquired infection in the NICU. Adv Neonat Care 2013, 13:154-163. quiz 164-155.

98. Rosenthal VD, Rodriguez-Calderon ME, Rodriguez-Ferrer M, Singhal T, Pawar M, Sobreyra-Oropeza M, Barkat A, Atencio-Espinoza T, Berba R, Navoa-Ng JA, Duenas L, Ben-Jaballah N, Ozdemir D, Ersoz G, Aygun C: Findings of the International Nosocomial Infection Control Consortium (INICC), Part II: Impact of a multidimensional strategy to reduce ventilator-associated pneumonia in neonatal intensive care units in 10 developing countries. Infect Control Hosp Epidemiol 2012, 33:704-710.

99. Zhou Q, Lee SK, Jiang SY, Chen C, Kamaluddeen M, Hu XJ, Wang CQ, Cao Y: Efficacy of an infection control program in reducing ventilator-associated pneumonia in a Chinese neonatal intensive care unit. Am J Infect Control 2013, 41:1059-1064.

doi:10.1186/2047-2994-3-30

Cite this article as: Aelami et al:: Ventilator-associated pneumonia in neonates, infants and children. Antimicrobial Resistance and Infection Control 2014 3:30

\section{Submit your next manuscript to BioMed Central and take full advantage of:}

- Convenient online submission

- Thorough peer review

- No space constraints or color figure charges

- Immediate publication on acceptance

- Inclusion in PubMed, CAS, Scopus and Google Scholar

- Research which is freely available for redistribution 